\title{
Aegean Territorial Waters Conflict: An Evolutionary Narrative
}

\author{
SERDAR Ş. GÜNER \\ Department of International Relations \\ Bilkent University \\ Bilkent, Ankara, Turkey
}

\begin{abstract}
Delimitation of the territorial waters and continental shelf in the Aegean Sea constitutes a constant source of conflict and produces recurrent crises between Greece and Turkey. This article explores directions that the Greek-Turkish dispute over the delimitation of territorial waters can take through an evolutionary game framework. Crises are found to follow routines and practices involving challenges to the status quo and reactions preceding mutual retreat. Hence, the status quo in the Aegean Sea can persist even in the form of aggressive behavior. It is also possible that the dispute will evolve into a stable state of conflict where no cooperative foreign policy can survive.
\end{abstract}

Keywords evolutionary game, equilibrium, hawks, doves, crisis cycles

Periodic crises over the delimitation of territorial waters in the Aegean Sea indicate a distinct pattern in relations between Greece and Turkey. While governments, political leaders, and sometimes regimes in both countries change, intermittent phases of conflict escalation and de-escalation punctuate Greek-Turkish relations. Lacking a theoretical perspective, the rich literature on the Aegean dispute and overall Greek-Turkish relations does not explain the recurrence of crises or predict possible future paths (see, among others, Bahcheli, 1990, 2000; Clogg, 1983; Constas, 1991; Coufoudakis, 1993, 1985; Couloumbis, 1983; Krebs, 1999; Larrabee, 1992; Papacosma, 1994; Veremis, 1984; Wilson, 1984). Why do these crises occur periodically? Should new crises be expected? In this paper, we attempt to answer these questions using an evolutionary game. The game analysis establishes a unique evolutionarily stable equilibrium characterized by persistent Greek challenges to the status quo in the Aegean Sea and aggressive Turkish reactions. The periodicity of hawkish (aggressive) and dovish (non-aggressive) foreign policies corresponds to evolutionary instability and recurrent crises.

First, we provide a succinct overview of the issue. We then lay out the framework that presents basic evolutionary game assumptions, the model, and the equilibrium conditions. The section on empirical analysis includes short histories of crises, the evolutionary narrative, and resulting implications. The conclusion points to possible extensions and applications of the model.

An earlier version of the paper was presented at the 16th Annual International Association for Conflict Management Conference, Melbourne, Australia, June 15-18, 2003. The author thanks Nedim M. Alemdar, Paul Williams, Nur Bilge Criss, and anonymous reviewers for detailed and constructive suggestions and comments.

Address correspondence to Serdar Ş. Güner, Deptartment of International Relations, Bilkent University, 06800, Bilkent, Ankara, Turkey. E-mail: sguner@bilkent.edu.tr 


\section{The Issue and Positions}

Currently, both countries, the only littoral states in the Aegean Sea, apply a six-mile limit to establish the breadth of their territorial waters. The current delimitation makes Greek territorial waters approximately equal to $43.68 \%$ of the Aegean, Turkish territorial waters $7.46 \%$, and the high seas up to $48.85 \%$. Should the Greeks begin applying the twelve-mile rule, as they claim to do on occasion, these percentages would respectively become $71.53 \%$, 8.76\%, and 19.71\% (Ahnish, 1993, 267-268, Wilson, 1984, 94).

The treaty of Lausanne fixed the extension of the littoral states' territorial waters at three miles in 1923. Greece extended its territorial waters to six miles in 1936. The current status quo formed when Turkey accepted the six-mile limit in 1964. According to the UN Convention on the Law of the Sea (UNCLOS), which was signed in 1982 and entered into force in 1994, signatory states have the right to expand their territorial waters out to twelve miles. Greece, unlike Turkey, is a signatory to the UNCLOS.

Greece considers the determination of its breadth of territorial waters to be a sovereign right. It claims that it will extend its territorial waters in the future. Since Turkey did not sign the treaty, Ankara considers the threatened Greek move as casus belli. ${ }^{1}$ Greece asserts that the Turkish position of casus belli is against Article 2, paragraph 4 of the UN Charter, according to which members cannot threaten others' territorial integrity. Turkey claims that its position stems from Article 300 of the UNCLOS, according to which parties can exercise the rights UNCLOS recognizes unless these create an abuse of right. Turkey insists that maritime transport between Turkish ports would require Greek permission if Greece extends its territorial waters up to twelve miles. According to Turkey, the Aegean is a semiclosed sea requiring the application of particular rules. Greece does not consider the Aegean as a semiclosed sea, therefore making the twelve-mile limit applicable.

The continental shelf issue is the only one that Greece considers negotiable regarding the Aegean Sea. Greece supports the territorial integrity thesis, according to which islands and the mainland form a contiguous whole. Turkey, on the other hand, supports drawing an equidistant line between Greek and Turkish continental land masses to delimit their respective continental shelves. The issues of the continental shelf and territorial waters are inextricably linked: "While most Aegean quarreling has centered on the continental shelf, the territorial sea issue is the one that is most vital for Turkey. The two issues are not unrelated, since all of the shelf claimed by Greece would accrue to it automatically, were it able to implement a twelve-mile territorial claim" (Bahcheli, 2000, 134). A revised status quo if both littoral states were to extend their territorial waters to twelve miles implies the undersea connection of the Greek mainland with thousands of Greek islands and islets scattered in the Aegean, and, therefore a considerable Greek gain of continental shelf (Ahnish, 1993, 269-270). Hence, overall, Greek and Turkish positions are strictly opposed over the Aegean Sea.

\section{Evolutionary Framework}

Evolutionary games are tools used to investigate modes of behavior in large populations of individuals such as insects, animals, plants, or humans. The survival of an individual in these populations may depend upon the mode of behavior adopted by all others. If almost every individual is passive, only a passive individual may survive in the population. Similarly, only a proactive individual may continue to exist in a largely proactive population. One mode of

${ }^{1}$ Greek and Turkish official positions are available on www.mfa.gr and www.mfa.gov.tr, respectively. 
behavior can produce a higher or a lower fitness (payoff) than another one depending upon the mode of behavior generally prevalent in a population.

In our case, individuals in the population are political leaders and high-ranking bureaucrats. They adopt modes of behavior termed "templates," that is, fixed strategic prescriptions implying ideas or procedures (Levy, 1994, 299). Numerous individuals can follow the same template. If almost all policymakers follow the same template, then those individuals who adhere to a different template may become extinct. The extinction of individuals has no biological meaning; instead, it implies individuals' conversion to the most successful mode of behavior.

Individuals are not assumed to possess perfect skills of computation and foresight (Kandori, Mailath, \& Rob, 1993, 29; Friedman, 1998, 20). While they can make mistakes, they imitate those who adhere to successful templates. Some templates bring higher fitness, and so, over time, more policymakers follow them. As a result, successful foreign policy procedures and ideas attract new followers. In evolutionary terms, imitated behavior drives foreign policy. Those templates that fail disappear gradually, because a lesser number of individuals tend to adopt them over time. Hence, learning is possible under limited rationality conditions. There is one limitation, though: the number of adherents to a template does not change too abruptly, as learning takes time (Fudenberg \& Levine, 1998, 88; Selten, 1991, 9-11).

Thus, in general, the evolutionary assumptions permit us to study slow changes in foreign policy. Specifically, the framework implies that: (1) Greek and Turkish modes of behavior over the Aegean territorial waters issue are not necessarily optimal when mutually paired; (2) these modes of behavior do not indicate a conscious effort to shape each other; (3) they do not suddenly change; (4) adherents to successful strategic prescriptions increase in number. Hence, first, some templates vanish while some survive, and, second, some are discovered to be working better than others through social learning or satisficing. The former refers to the imitation of templates bringing higher than average payoffs and the latter to the reinforcement of those that "do well" in the sense of following routines and engaging in myopic search rather than rational optimization (Fudenberg \& Levine, 1998, 87-95; Allison, 1971, 67-100).

\section{The Model}

We assume, for the sake of simplicity, that only two templates exist: the hawk and the dove. The Greek hawk, unlike the Greek dove, challenges the status quo in the Aegean Sea. Similarly, the Turkish hawk supports aggressive action, unlike the Turkish dove. Hawkish and dovish templates prescribe different actions in Greek and Turkish populations. Hence, Greek and Turkish populations are assumed to be strategically distinct from each other. These definitions approximate empirical observations of Greek-Turkish conflict over the Aegean Sea and the, respectively, aggressive/nonaggressive traits of hawks and doves in theory.

Hawks and doves of one population are repeatedly and randomly matched to those of the other. This yields the following possible pairs: Greek hawk versus Turkish hawk (hawk-hawk), Greek dove versus Turkish dove (dove-dove), Greek hawk versus Turkish dove (hawk-dove), and Greek dove versus Turkish hawk (dove-hawk). If hawks (doves) obtain a higher average fitness, then the fraction of hawks (doves) grows in the population, and, accordingly, foreign policy becomes progressively hawkish (dovish).

The status quo remains intact in dove-dove contests, as Greek doves do not challenge the status quo and Turkish doves do not aggressively react. The status quo payoffs are normalized to zero for convenience. The payoffs realized in other pairs are measured relative to the outcome of dove-dove contests. 
Hawk-hawk contests, which consist of a Greek challenge and a Turkish reaction, are conflictive and therefore costly. Both sets of hawks either win resources or lose and suffer costs. The value of the undisturbed status quo is the Turkish resource. If Turkish hawks win, the status quo is not upset, similar to the outcome in dove-dove encounters. Accordingly, successful Turkish hawks in hawk-hawk contests obtain zero and may even fail and suffer some costs in these encounters. While the Greek territorial-waters surplus is approximately $36 \%$ under the six-mile limit, it will become $63 \%$ if the twelve-mile norm becomes the rule. The Greek territorial increment, which will then be about $27 \%$, is defined as the Greek resource. Thus, successful Greek hawks obtain 0.27 in hawk-hawk contests. Yet, it is also likely that Greek hawks fail and suffer some costs when they face Turkish hawks.

Therefore, Turkish hawks face the following lottery in hawk-hawk encounters: $\mathrm{p}(0)+$ $(1-\mathrm{p})\left(-\mathrm{W}_{\mathrm{T}}\right)=\mathrm{W}_{\mathrm{T}}(\mathrm{p}-1)$, where $-\mathrm{W}_{\mathrm{T}}$ denotes costs Turkish hawks suffer when matched with Greek hawks, $p$ the likelihood that Turkish hawks prevail in their encounters with Greek hawks, and $(1-p)$ the likelihood that Greek hawks prevail when they are matched with Turkish hawks. ${ }^{2}$ Greek hawks similarly expect $\mathrm{p}\left(-\mathrm{W}_{\mathrm{G}}\right)+(1-\mathrm{p})(0.27)=-\mathrm{W}_{\mathrm{G}} \mathrm{p}+$ $(1-p) 0.27$, where $-\mathrm{W}_{\mathrm{G}}$ denotes costs Greek hawks suffer in hawk-hawk contests. We assume that $1>\mathrm{p}>0$. Hawks, either Greek or Turkish, do not win resources or suffer costs with certainty when paired with each other. The expected payoffs of outcomes where hawks are matched with hawks reflect that the values of the resource, that is, the Greek gain from a revised status quo and the Turkish gain from a continued status quo, are reduced by respective costs.

Greek hawks challenge the status quo and Turkish doves do not retaliate. As a result, a new status quo is obtained in hawk-dove contests, with Greek hawks simply obtaining $27 \%$ and suffering no costs. The Greek territorial increment also reduces Turkish territory by the same amount in the Aegean Sea in the context of diametrically opposed Greek and Turkish positions. Greek hawks and Turkish doves therefore obtain 0.27 and -0.27 in their encounters, respectively. Turkish doves suffer a tremendous loss when paired with Greek hawks. Accordingly, Turkish hawks are assumed to be more successful than Turkish doves when both types encounter Greek hawks: $-0.27<\mathrm{W}_{\mathrm{T}}(\mathrm{p}-1)$.

In contrast to hawk-dove encounters, both types suffer costs and realize no gains in dove-hawk contests. The Greek dove does not challenge the status quo, but the Turkish hawk reacts. Both types suffer costs from Turkish bellicosity. The parameters $-U_{G}$ and $-U_{T}$ measure, respectively, the costs of Greek doves and Turkish hawks in dove-hawk contests. Failures in fully conflictive hawk-hawk contests generate high costs. Therefore, Greek doves paired with Turkish hawks are assumed to experience lesser costs than failing Greek hawks in hawk-hawk contests: $-\mathrm{W}_{\mathrm{G}}<-\mathrm{U}_{\mathrm{G}}$. Turkish hawks also attract international reactions against their unfounded aggressiveness. These reactions can even offset Greek doves' costs and produce net benefits for Greek doves.

These assumptions imply the game shown in Figure 1.

\section{Equilibria}

Let $x$ be the fraction of Turkish hawks in the Turkish population. The fraction of Turkish doves is therefore $1-x$. In the Greek population, hawk and dove fractions are, respectively, $y$ and $1-y$. We now compute expected payoffs for each template in Greek and Turkish populations.

\footnotetext{
${ }^{2}$ The likelihood $\mathrm{p}$ does not denote Greek and Turkish perceptions of Turkish victory.
} 


\begin{tabular}{|c|c|c|}
\hline Stage Game & Greek Hawk & Greek Dove \\
\hline Turkish Hawk & $(\mathrm{p}-1) \mathrm{W}_{\mathrm{T}},-\mathrm{pW}_{\mathrm{G}}+(1-\mathrm{p}) 0.27$ & $-\mathrm{U}_{\mathrm{T}},-\mathrm{U}_{\mathrm{G}}$ \\
\hline Turkish Dove & $-0.27,0.27$ & 0,0 \\
\hline
\end{tabular}

FIGURE 1 The game.

Greek hawks expect

$$
x\left[-\mathrm{W}_{\mathrm{G}} \mathrm{p}+(1-\mathrm{p}) 0.27\right]+(1-x)(0.27)
$$

as the probability of being matched with a Turkish hawk is $x$ and the probability of being matched with a Turkish dove is $1-x$. Similarly, for Greek doves, we have

$$
x\left(-\mathrm{U}_{\mathrm{G}}\right)+(1-x)(0)=x\left(-\mathrm{U}_{\mathrm{G}}\right)
$$

since they are matched with a Turkish hawk with probability $x$ and with a Turkish dove with probability $1-x$.

Turkish hawks expect

$$
y\left[\mathrm{~W}_{\mathrm{T}}(\mathrm{p}-1)\right]+(1-y)\left(-\mathrm{U}_{\mathrm{T}}\right),
$$

as they can be matched with probability $y$ with a Greek hawk and with probability $1-y$ with a Greek dove. As to Turkish doves, they can encounter either Greek hawks or Greek doves with $y$ and $1-y$ probabilities, respectively. Therefore, they expect

$$
y(-0.27)+(1-y)(0)=-0.27 y .
$$

In the Greek population, hawks have a greater fitness than doves when

$$
x\left[-\mathrm{W}_{\mathrm{G}} \mathrm{p}+(1-\mathrm{p}) 0.27\right]+(1-x)(0.27)>x\left(-\mathrm{U}_{\mathrm{G}}\right)
$$

Let $\gamma_{1}$ denote the ratio $\left(0.27+\mathrm{U}_{\mathrm{G}}\right) /\left(0.27+\mathrm{W}_{\mathrm{G}}\right)$. If $\mathrm{p}>\gamma_{1}$, the following conditions are implied.

1. If $0.27 /\left[\mathrm{p}\left(\mathrm{W}_{\mathrm{G}}+0.27\right)-\mathrm{U}_{\mathrm{G}}\right]>x$, then the proportion of Greek hawks increases in the Greek population.

2. If $0.27 /\left[\mathrm{p}\left(\mathrm{W}_{\mathrm{G}}+0.27\right)-\mathrm{U}_{\mathrm{G}}\right]<x$, then the proportion of Greek doves increases in the Greek population.

In the Turkish population, the hawk fitness is greater when:

$$
y\left[\mathrm{~W}_{\mathrm{T}}(\mathrm{p}-1)\right]+(1-y)\left(-\mathrm{U}_{\mathrm{T}}\right)>-0.27 y .
$$

Thus we obtain the following further conditions. 
3. If $\mathrm{U}_{\mathrm{T}} /\left[\mathrm{U}_{\mathrm{T}}+0.27+\mathrm{W}_{\mathrm{T}}(\mathrm{p}-1)\right]<y$, then the proportion of Turkish hawks increases in the Turkish population.

4. If $\mathrm{U}_{\mathrm{T}} /\left[\mathrm{U}_{\mathrm{T}}+0.27+\mathrm{W}_{\mathrm{T}}(\mathrm{p}-1)\right]>y$, then the proportion of Turkish doves increases in the Turkish population.

Let $\alpha$ and $\beta$ denote, respectively, $\mathrm{U}_{\mathrm{T}} /\left[\mathrm{U}_{\mathrm{T}}+0.27+\mathrm{W}_{\mathrm{T}}(\mathrm{p}-1)\right]$ and $0.27 /\left[\mathrm{p}\left(\mathrm{W}_{\mathrm{G}}+\right.\right.$ $\left.0.27)-\mathrm{U}_{\mathrm{G}}\right]$. Both thresholds are positive, smaller than 1, and indicate population mixtures. They generate four cells numbered clockwise I, II, III, and IV in the phase diagram in Figure 2.

Greek and Turkish doves expand in the cell I, Greek hawks and Turkish doves expand in the cell II, Greek and Turkish hawks expand in the cell III, Greek doves and Turkish hawks expand in the cell IV. Boldface arrows indicate a continuous clockwise rotation in hawk-dove mixtures in Greek and Turkish populations and therefore no evolutionary stability.

The variations in $\mathrm{U}_{\mathrm{G}}$ and $\mathrm{W}_{\mathrm{G}}$ modify the critical ratio $\gamma_{1}$ that decrease in $\mathrm{W}_{\mathrm{G}}$ and increase in $\mathrm{U}_{\mathrm{G}}$. The ratio $\gamma_{1}$ increases when, paired with Turkish hawks, the costs of Greek doves increase or the costs of Greek hawks decrease. As there are lesser chances for $p$ to exceed higher values of $\gamma_{1}$, the prospects for Greek and Turkish doves to become extinct are higher in this case. Hence, an acute conflict can become evolutionarily stable. Otherwise, if Greek doves suffer less than Greek hawks in their respective encounters with Turkish

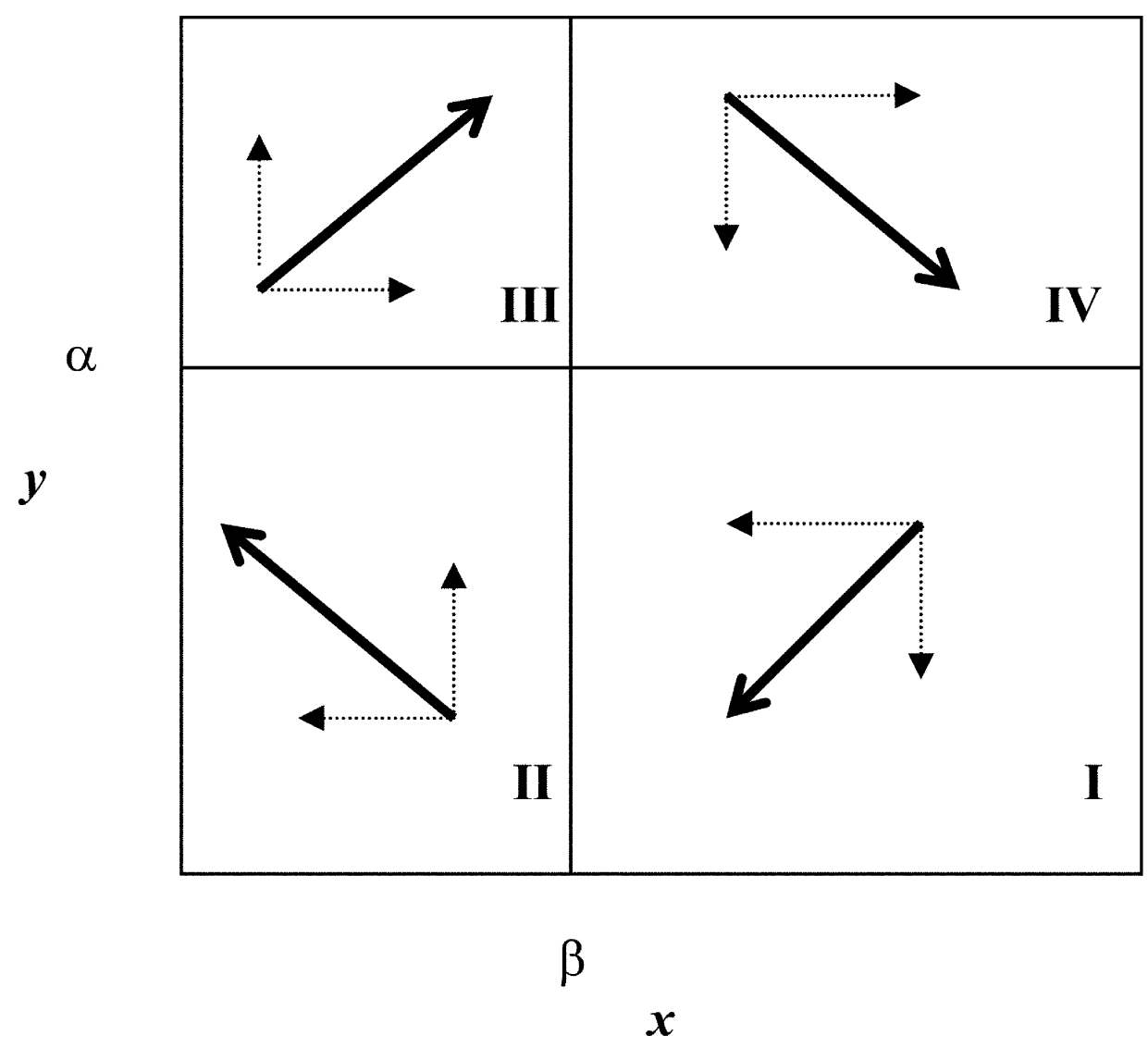

FIGURE 2 Phase diagram 1. 


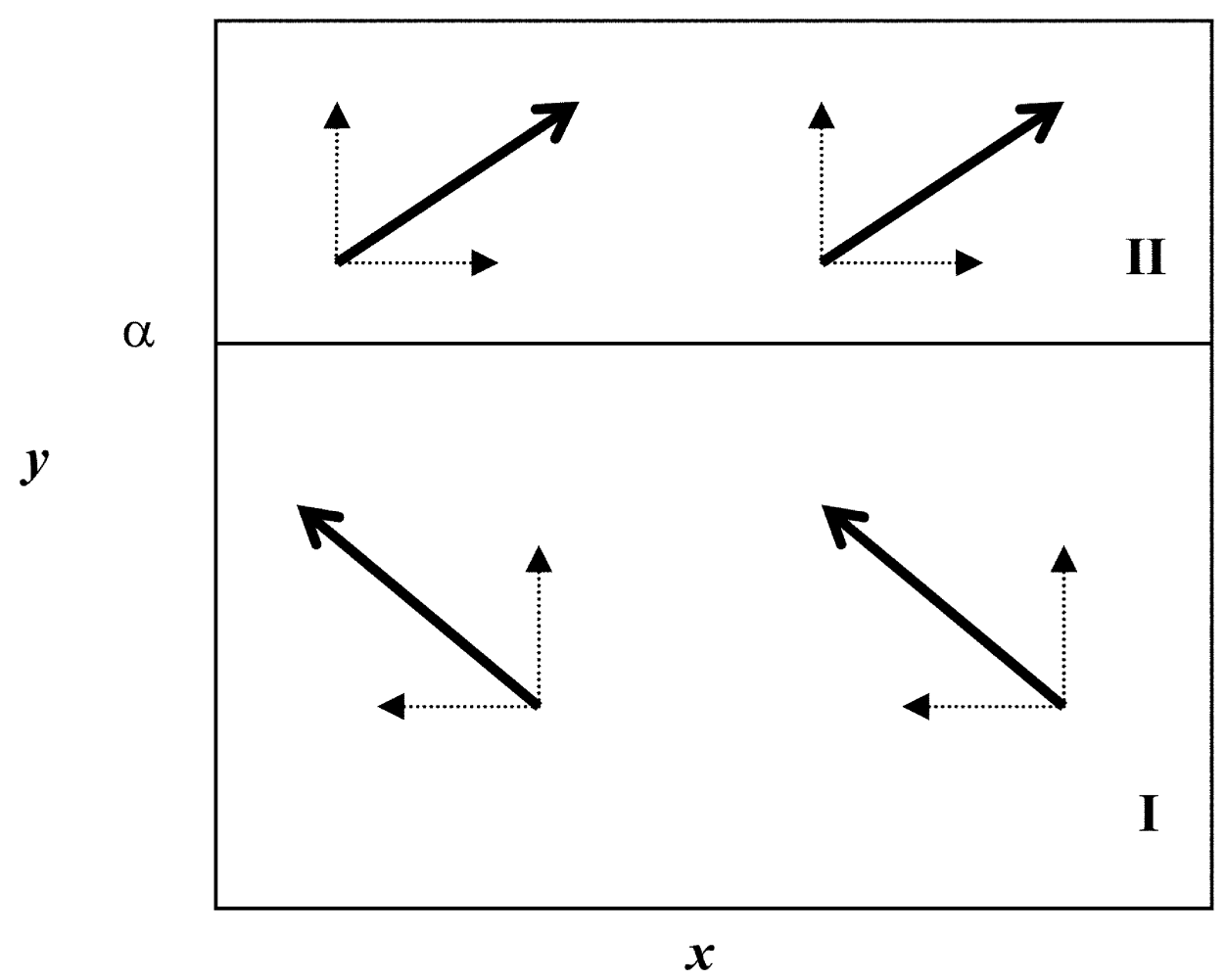

FIGURE 3 Phase diagram 2.

hawks, the ratio becomes smaller. As a result, there are greater chances for $p$ to exceed lower values of $\gamma_{1}$ and for crises and détente periods to recur in succession.

If $\mathrm{p}<\gamma_{1}$, hawkish templates become evolutionarily stable in both populations. Greek hawks repeatedly achieve a greater fitness than Greek doves given that Turkish hawks prevail with a probability less than $\gamma_{1}$. There no longer exists a threshold under which Greek hawks could lose the influence in the Greek population. As a result, Greek hawks proliferate until they comprise the whole population, while Greek doves become extinct. In the phase diagram in Figure 3, Turkish doves fare better than Turkish hawks as long as the fraction of Greek hawks stays below $\beta$ (cell I). Turkish hawks become more successful than Turkish doves once the growth of the Greek hawk fraction exceeds $\beta$. Hence, Turkish hawks multiply in the Turkish population as well. If Greek hawks are so numerous as to already make up a fraction greater than $\beta$ (cell II), then Turkish hawks only obtain a higher fitness. Therefore, if $\mathrm{p}<\gamma_{1}$, Greek-Turkish relations over the Aegean Sea evolve towards a stable but conflictive situation as doves disappear in both populations.

If Greek doves benefit from Turkish aggression, the condition for greater hawk fitness in the Greek population becomes

$$
x\left[-\mathrm{W}_{\mathrm{G}} \mathrm{p}+(1-\mathrm{p}) 0.27\right]+(1-x)(0.27)>x\left(\mathrm{U}_{\mathrm{G}}\right) .
$$

Provided that $\mathrm{p}>\left(0.27-\mathrm{U}_{\mathrm{G}}\right) /\left(0.27+\mathrm{W}_{\mathrm{G}}\right)$, the following conditions are implied:

5. If $0.27 /\left[\mathrm{p}\left(\mathrm{W}_{\mathrm{G}}+0.27\right)+\mathrm{U}_{\mathrm{G}}\right]>x$, then the proportion of Greek hawks increases in the Greek population. 
TABLE 1 Evolutionary implications

\begin{tabular}{|c|c|c|c|}
\hline Conditions on $p$ & $\begin{array}{l}\text { Turkish fitness } \\
\text { assumptions }\end{array}$ & $\begin{array}{l}\text { Greek fitness } \\
\text { assumptions }\end{array}$ & Evolutionary stability \\
\hline $1>p>0$ & $0>-\mathrm{W}_{\mathrm{T}},-\mathrm{U}_{\mathrm{T}}$ & \multirow[t]{2}{*}{$0>-\mathrm{U}_{\mathrm{G}}>-\mathrm{W}_{\mathrm{G}}$} & No evolutionary stability \\
\hline$p>\gamma_{1}$ & $-0.27<\mathrm{W}_{\mathrm{T}}(\mathrm{p}-1)$ & & Recurrent crises \\
\hline $1>p>0$ & $0>-\mathrm{W}_{\mathrm{T}},-\mathrm{U}_{\mathrm{T}}$ & \multirow[t]{2}{*}{$\mathrm{U}_{\mathrm{G}}>0>-\mathrm{W}_{\mathrm{G}}$} & No evolutionary stability \\
\hline$p>\gamma_{2}$ & $-0.27<\mathrm{W}_{\mathrm{T}}(\mathrm{p}-1)$ & & Recurrent crises \\
\hline $1>p>0$ & $0>-\mathrm{W}_{\mathrm{T}},-\mathrm{U}_{\mathrm{T}}$ & \multirow[t]{2}{*}{$0>-\mathrm{U}_{\mathrm{G}}>-\mathrm{W}_{\mathrm{G}}$} & Evolutionary stability: \\
\hline$p<\gamma_{1}$ & $-0.27<\mathrm{W}_{\mathrm{T}}(\mathrm{p}-1)$ & & Doves get extinct. \\
\hline $1>p>0$ & $0>-\mathrm{W}_{\mathrm{T}},-\mathrm{U}_{\mathrm{T}}$ & \multirow[t]{2}{*}{$\mathrm{U}_{\mathrm{G}}>0>-\mathrm{W}_{\mathrm{G}}$} & Evolutionary stability: \\
\hline$p<\gamma_{2}$ & $-0.27<\mathrm{W}_{\mathrm{T}}(\mathrm{p}-1)$ & & Doves get extinct. \\
\hline
\end{tabular}

6. If $0.27 /\left[\mathrm{p}\left(\mathrm{W}_{\mathrm{G}}+0.27\right)+\mathrm{U}_{\mathrm{G}}\right]<x$, then the proportion of Greek doves increases in the Greek population.

The evolutionary trajectories do not change without altering Turkish fitness assumptions. Let $\gamma_{2}$ denote the ratio $\left(0.27-\mathrm{U}_{\mathrm{G}}\right) /\left(0.27+\mathrm{W}_{\mathrm{G}}\right)$. There is no evolutionary stability provided that $\mathrm{p}>\gamma_{2}$; otherwise, an evolutionary stability is reached if $\mathrm{p}<\gamma_{2}$.

The ratio $\gamma_{2}$ decreases in both $\mathrm{W}_{\mathrm{G}}$ and $\mathrm{U}_{\mathrm{G}}$. The higher these parameters, the greater are the chances for $p$ to exceed a low $\gamma_{2}$. Hence, if the benefits that accrue to Greek doves from Turkish reactions or the costs to Greek hawks of being paired with Turkish hawks increase, then there are greater prospects for no evolutionary stability. Otherwise, Greek-Turkish controversy over the Aegean Sea will reach a state of stable conflict.

Overall, the survival of doves separates crises from acute conflicts. In acute conflicts, both populations contain hawks only and the prospect of war appears as genuine as in brinkmanship crises. However, crises taper off with the growth of doves in at least one population. Hence, the difference between brinkmanship crises and acute conflicts is the survival of doves. Mutant doves have no chance of surviving in acute conflicts.

Table 1 summarizes overall conditions for evolutionary stability and instability.

\section{Empirical Analysis}

\section{Crises}

Recurrent crises are observable. As Table 2 indicates, they correspond to different governments in power in Greece and Turkey. ${ }^{3}$

\section{Crisis 1}

Greece granted oil exploration licenses in the Aegean Sea in 1970; this oil was discovered to cover about 10\% of Greek oil requirements in 1972 (Papacosma, 1996, 81). Although Greece claimed it was granting these licenses for oil exploration on its own continental shelf, there was no immediate Turkish reaction. In fact, the Turkish government under the premiership of Naim Talu permitted the Turkish national oil company to drill in high seas in November 1973.

Demetrios Ioannidis, a hard-line member of the Greek junta, overthrew George Papadopoulos (the chief engineer of the 1967 military coup) in November 1973.

${ }^{3}$ Data sets on international crises and territorial conflicts do not indicate the sizes of hawk and dove factions in interacting populations (Brecher \& Wilkenfeld, 1997; Huth, 1998). 
TABLE 2 Greek and Turkish prime ministers, 1972-2003.

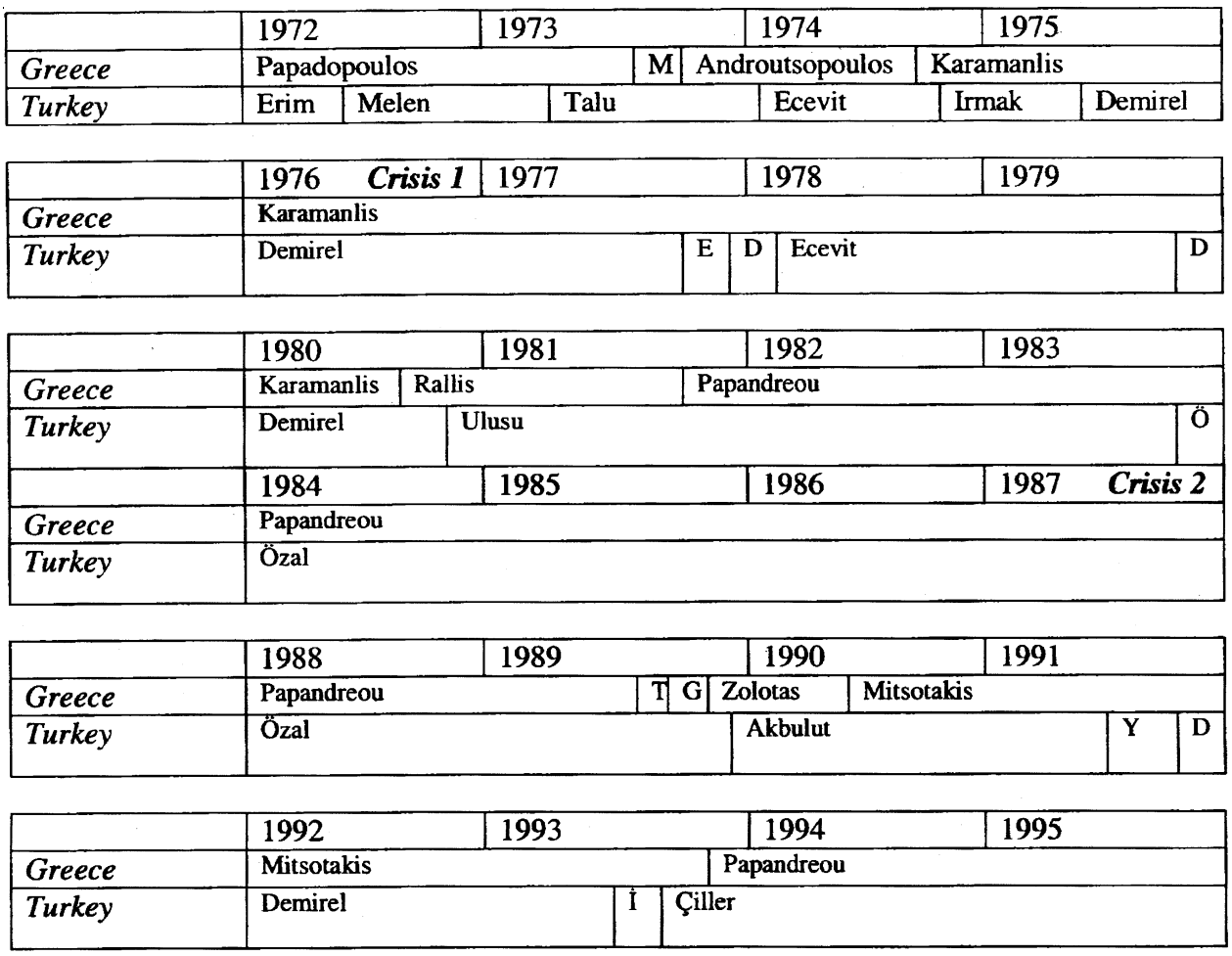

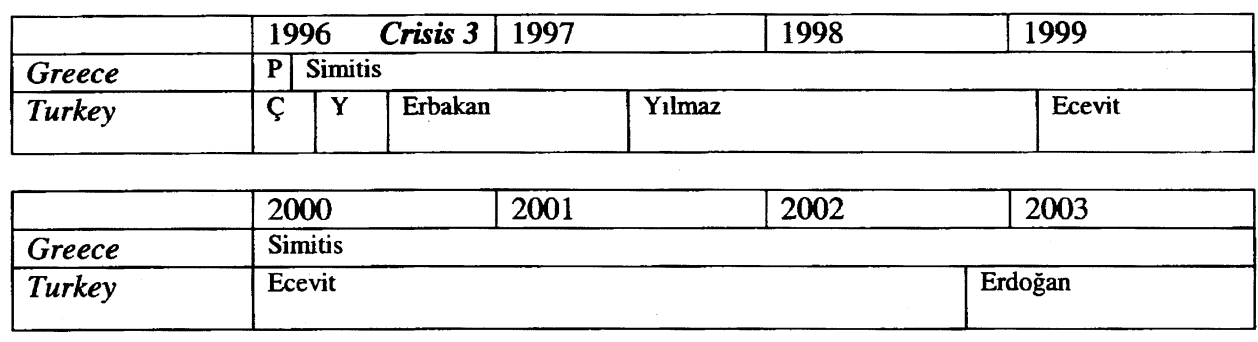

Legend: M: Markezinis, T: Tzannetakis, G: Givas, P: Papandreou: E: Ecevit, D: Demirel, Y: Yılmaz. İ: İnönü, Ç: Çiller.

Greek-Turkish relations reached a nadir after Ioannidis and his supporters came to power. The Turkish government led by Bülent Ecevit, a moderate left-leaning, populist leader, replaced the government of Naim Talu in January 1974. Key Turkish bureaucrats were more receptive to a firmer and a more active foreign policy in response to Greek actions in the Aegean. Indeed, in May 1974, a Turkish ship escorted by warships conducted a seismic search in disputed areas. Under Greek protests, Turkey argued that these areas were on a line extending from the Anatolian peninsula and forming the Turkish continental shelf. Greek and Turkish troops went on alert. The crisis remained insignificant next to the developments in Cyprus and the Turkish military intervention on the island in July 1974 (Bahcheli, 1990, 131).

Constantine Karamanlis, a moderate-right Greek leader, assumed government power in July 1974 after the military junta was ousted. The Greek search for oil in disputed areas nonetheless continued under the leadership of Karamanlis. By that time, there were also political changes in Turkey. Süleyman Demirel, a moderate-right leader, was the Turkish 
premier, with Bülent Ecevit in opposition. The Demirel government later abandoned the idea of adjudicating the conflict following harsh criticism from the opposition and opted for a more assertive foreign policy. An acute crisis arose in August 1976 after Sismik I, a Turkish exploration ship, started to conduct seismic research. PASOK leader Andreas Papandreou demanded that the Greek government sink the Turkish ship, making an overt conflict imminent. ${ }^{4}$ Given the severe nature of the Greek reaction, the Turkish government declared that any move by Greece to extend its territorial waters would constitute a casus belli.

The Karamanlis government did not order the sinking of Sismik I, as recommended by Papandreou; rather, it submitted the case to the UN and the International Court of Justice. These political moves resulted in a denial of the Greek request by the International Court of Justice and in a resolution by the UN Security Council. The tension later eased with a Greek-Turkish agreement signed in Bern in November 1976. Greece and Turkey pledged to keep each other informed about their exploration activities and to respect the status quo in the Aegean Sea.

\section{Crisis 2}

Andreas Papandreou formed the government after his party won the general elections of 1981. The Bern agreement did not survive the electoral victory of PASOK: "Bilateral relations resumed in earnest after Berne, and although no settlement emerged, neither side questioned their usefulness until Andreas Papandreou's PASOK government came to power in Greece in 1981" (Bahcheli, 1990, 137). PASOK indeed followed a hard-line policy regarding the Aegean issue (Wilson, 1984, 115).

A similar type of crisis occurred in 1987. Greece started to grant licenses for oil exploration once again, disregarding the Bern agreement. Turkey reacted by launching an exploration ship out the high seas and the two countries' forces were mobilized subsequently. While the situation could easily have culminated in a Greek-Turkish war during late March, following the movement of the Turkish ship in disputed waters, tension eased within days, as Prime Ministers Andreas Papandreou and Turgut Özal met in Davos and reached an understanding.

\section{Crisis 3}

The two countries nonetheless relived another crisis in 1996, this time over the Imia/ Kardak rocks. These islets lie 3.8 miles off the Turkish coast and 5.3 miles from the Greek island Kalymnos. Tension rose after a Turkish ship ran aground on one of these rocks. The conflict escalated when Greek and Turkish military forces were dispatched to the area. The crisis died out a few weeks later. Greek Prime Minister Kostas Simitis (PASOK) and Turkish President Süleyman Demirel issued the Madrid Communiqué in 1997 at the NATO summit, where they stressed the importance of peaceful relations and cooperation between their countries.

\section{Evolutionary Narrative}

The Greek search for oil in 1970 in disputed waters prima facie indicates that the fraction of the Greek population that challenges the status quo in the Aegean Sea was on the rise. Hawkish Greek policy was rooted in the military dictatorship that governed Greece between 1967 and 1974. The extreme right-wing colonels forming the Greek junta preferred tough policies against Turkey (Veremis, 1984, 18). Wilson $(1984,112)$ remarks that there

\footnotetext{
${ }^{4}$ PASOK is the Greek acronym for the Pan-Hellenic Socialist Movement.
} 
was "no Turkish reaction" to Greek claims for three years. Thus, Greek hawks repeatedly encountered acquiescent Turkish doves. Greek hawks were more successful than Greek doves, with Turkish hawks constituting a fraction lower than $\beta$. Imitating the successful template, a greater number of Greek policymakers were converted to hawks. As a result, Greek foreign policy became gradually more hawkish. Greek hawks and Turkish doves expanded for a period corresponding to cell II of the phase diagram 1 (Figure 2). The evolutionary trajectory then took a turn upward and approached $\alpha$.

Consentient Turkish foreign policy declined once Greek hawks constituted a fraction higher than $\alpha$. Turkish hawks did not lose the Turkish resource in the Aegean Sea as certainly as Turkish doves did. Thus they began to obtain a greater fitness than Turkish doves in relatively frequent encounters with Greek hawks. The Talu government's reaction in 1973 lends credibility to the onset of the hawks' rise in the Turkish population: "having failed to challenge the Greeks in the Aegean for more than a decade (until 1973), the Turks wanted to avoid the appearance of acquiescence" (Bahcheli, 1990, 134). The propagation of Greek hawks triggered the growth of Turkish hawks. For example, Bülent Ecevit criticized the Demirel government's agreement to bring the continental shelf issue to the International Court of Justice. Wilson $(1984,109)$, commenting on Ecevit's behavior, notes: "This was the more remarkable in view of Mr Ecevit's record in opposition, where he had frequently spurred Turkish governments, such as Demirel's in 1976, to take a harder line than they had intended." Thus, hawks expanded in both populations as successful templates were passed on by imitation; accordingly, the state of Greek-Turkish relations over the Aegean Sea reached the conditions captured in cell III (Figure 2).

Hawks continued to increase as a proportion of their respective populations later in May 1974, reaching their peak in the August 1976 crisis. The crisis phased out in cell IV, given that Greek doves were more successful than Greek hawks when matched with an increasing number of Turkish hawks. In terms of this study, Turkish hawks must have come to constitute a fraction higher than $\beta$ in the Turkish population. However, as reactions are costly, Turkish doves obtained in turn a greater fitness than Turkish hawks once the fraction of Greek hawks dropped below $\alpha$. Consequently, the evolutionary trajectory turned downward. Greek and Turkish doves were repeatedly imitated and the evolution of foreign policies reached cell I. The Bern agreement in November 1976 indicated the corresponding accumulation of doves in Greek and Turkish populations.

The evolutionary game implies that the fraction of Greek hawks grew in frequent encounters with acquiescent Turkish doves following the Bern agreement. The hawkish turn in the Greek foreign policy was not sudden but steady. Greek policymakers did not initially discover that to challenge the status quo produced strictly greater benefits than to follow the dovish template. Learning took time. In fact, the PASOK victory in the 1980 elections was indicative of a progressively hawkish Greek foreign policy. The PASOK government labeled Turkey as the sole threat to Greece and supported a more hard-line position over the Aegean Sea (Papacosma, 1996, 91). A former Turkish ambassador to Athens recalls this policy shift: "At the end of February 1987 a consortium of companies called the Northern Aegean Petroleum Company announced that it would start drilling for oil on the continental shelf 10 miles off the island of Thasos. ... the Turkish government still expected Greece to abide by the rules of Bern agreement.... Mr. Kapsis retorted that the Greek government considered Bern Agreement as 'inoperative,' therefore it would decide to drill when and wherever it likes in the Aegean" (Akıman, 2000, 4-5). The state of Greek-Turkish relations again reached cell II.

Turkish foreign policy became increasingly hawkish once the fraction of Greek hawks exceeded $\alpha$. The Turkish reaction of sending a ship to the Aegean Sea in 1987 indicated the rise of Turkish hawks following the Greek policy change. The 1987 crisis died out just as 
the crisis of 1976 did. Commenting on the 1987 tensions, Turkish Prime Minister Turgut Özal wished that "such a crisis should never be repeated" (Pridham, 1991, 80). The Davos rapprochement signaled the growth of doves in both populations returning the game to cell I once more. The third crisis over İmia/Kardak rocks and the subsequent period of détente as indicated by the Madrid meeting between Simitis and Demirel therefore smack of déjà vu. Nowadays, Greece and Turkey follow dovish foreign policies, but the model predicts that hawks will rise once again in both populations.

The balance of military capabilities is an important indicator of war costs and the probability of prevailing in conflict. Huth and Russett $(1993,65)$ take the balance of active manpower as an indicator of the balance. According to Smith, Sola, and Spagnolo (2000, 741 ), the balance of military capability indicates the probability of prevailing in a conflict. Huth, Bennett, and Gelpi $(1993,613)$ maintain that the country enjoying superiority in the balance of conventional capabilities has a higher probability of victory and also would suffer lesser war costs.

Turkey possesses the second largest army in NATO, surpassed only by that of the United States. Turkey's population and the size of its total armed forces have exceeded those of Greece by a wide margin. ${ }^{5}$ As the balance of forces has favored Turkey, it can be assumed that the Turkish probability of prevailing in a conflict was high. Greek-Turkish relations could have unfolded into a stable conflict provided that the Turkish likelihood of prevailing remained below certain ceilings $\left(\gamma_{1}\right.$ and $\left.\gamma_{2}\right)$. However, Greek-Turkish relations over the Aegean Sea never reached the state of stable conflict, as demonstrated by the recurrence of crises and cooling off periods. Doves were never completely overwhelmed by hawks and continued to survive; they even dominated the respective populations at times. Thus, the unique evolutionarily stable equilibrium the model implies has no empirical support. Such a result corroborates rationalist deterrence explanations, according to which challengers ultimately back down given high prospects of a costly defeat (Huth \& Russett, 1993; Hensel, 1994).

\section{Implications}

In the phase diagram 1 (Figure 2), the process bridging cell III and cell IV evokes brinkmanship crises where one party steps down once conflict reaches a high tension level with an imminent prospect of war (Dixit \& Nalebuff, 1991; Fearon 1994; Nalebuff, 1986; Powell, 1990; Schelling, 1960; Snyder \& Diesing, 1977). Evolutionary interpretation revises the concept of brinkmanship crisis in two respects. First, brinkmanship is a conscious strategy that includes calculation of risks of a costly outcome and deliberate moves to push an adversary to the brink of war. Fearon $(1994,577)$ defines crises as "political attrition contests where a state can choose to attack, to back down, or escalate further." Evolutionary games lack such calculations, deliberate thinking, and purposes. Brinkmanship crises can be reached through routines, rules of thumb, and imitation. Thus, produced involuntarily, they do not necessarily result from conscious calculation of risks and benefits. Second, the game implies and indicates a brink after which tension lessens in crises. Commenting on the most dangerous crisis of the Cold War, Dixit and Nalebuff $(1991,207)$ maintain: "Just where was the brink in the Cuban missile crisis?.. The answer, of course, is that there was no such precise point, only a gradually increasing risk of uncontrollable future escalation."

${ }^{5}$ For example, Greece and Turkey have population figures of 10,692,00 and 66,130,000 for 2000-2001, respectively. These figures are 8,750,000 and 34,000,000 for 1969-1970. In 1969-1970 the sizes of the Greek and Turkish armed forces (active on duty) were, respectively, 159,000 and 483,000. In 2000-2001 they became 159,170 and 609,700 (Source: The Military Balance, Institute for Strategic Studies, London.) 
The evolutionary game exposes the brink (the $\beta$ threshold in the phase diagram 1, Figure 2) once the evolution of foreign policies reaches cell III.

Bahcheli $(1990,134)$ argues that "domestic pressures were instrumental" in the outbreak of the 1976 crisis. The model implies that not domestic pressures, but Greek policymakers' adherence to the successful hawkish template precipitated the crisis. Süleyman Demirel and other members of the Turkish population also had to adopt an active policy bringing higher returns rather than being compliant in the face of Greek challenges. Thus, the sending of a ship into disputed waters did not necessarily depend upon different personalities of Turkish leaders in power.

Greek foreign policy would also become dovish, albeit at a slow pace, when facing a greater number of Turkish hawks. Pridham $(1991,82)$ claims that "Papandreou's sudden transformation into a peacemaker, in contrast to his previous line towards Turkey, contained a good degree of political opportunism." Similar to Karamanlis, however, Papandreou became a "peacemaker" not because of domestic political concerns, but because Turkish foreign policy became far more hawkish during the crisis than in the initial years of PASOK rule in Greece. Then it was rewarding to be a dove in the Greek population.

Papacosma (1996) and Kazamias (1997) argue that the PASOK electoral victory in 1981 caused a sudden inflection in Greek foreign policy. However, the first serious crisis over the Aegean erupted when PASOK was not in government. The second crisis did not occur in 1981 or 1982 either, but broke out six years after PASOK's electoral victory. Foreign policies did not change overnight.

The evolutionary analysis also implies that regime type did not affect evolution. It made no difference whether a democratic government or a military junta ruled Greece or Turkey. Individuals, either military or civilian, simply imitated those who adhered to successful templates. For example, Greece's passage from military rule to democracy did not end Greek challenges to the status quo in the 1970s. Moreover, Greece decided to leave NATO's military wing following the Cyprus war in 1974. The Turkish military junta lifted the Turkish veto against such a return in 1980 . Hence, the military did not necessarily adopt an aggressive mode of behavior, and they were not more aggressive than civilian members of the population (Veremis, 1984, 28).

The model does not predict a costless revision of the status quo. Arguments relying upon rational learning and inferences could imply that a peaceful end to the Aegean rivalry becomes likely if Greece or Turkey convinces the other that its expectations regarding territorial waters are untenably costly (Thompson, 1995, 220). Turkish military supremacy over Greece can help to explain the current peaceful status quo punctuated by crises, as no inconsistent expectations about the outcome of war are possible under these conditions (Blainey, 1988). Alternatively, one could explain the status quo as it represents benefits to Turkey and Greece concordant with the cross-distribution of power (Powell, 1999, 85). These explanations differ from the evolutionary approach that permits mistakes, imitation of successful procedures, and fixed modes of behavior over time. Evolutionary arguments produce alternative explanations and clarify general conditions under which crises may arise and phase out with their eventual outcomes (Huth \& Russett, 1993).

Rational learning is indeed the focus of various works on repeated conflicts and crises. Maoz and Mor (1999) present a game-theoretic analysis allowing a venue for studying how preferences and games change through experiential learning and perceptions. According to their model, Greek and Turkish learning leading to misperceptions would also produce recurrent crises, while learning that leads to no behavioral change would increase the chances of peaceful interactions over the Aegean Sea. Leng $(1983,1988)$ finds that unsuccessful challengers in a crisis use more coercive strategies in the next one and that successful strategies are imitated in crises involving relatively equal capabilities. We find that unsuccessful 
Greek hawks vis-à-vis a hawkish Turkish population did not become more coercive in subsequent crises. In addition, Leng (2000, 10-11) defines hawks and doves as having beliefs in coercive bargaining and problem solving, respectively. In Soviet-American, EgyptianIsraeli, and Indo-Pakistani rivalries, rational decision makers draw lessons and evaluate gains and costs of being hawkish or dovish in the next crisis depending upon past crises. Therefore, Leng (1983, 1988, 2000) and Maoz and Mor (1999) do not present evolutionary arguments.

\section{Conclusion}

The evolutionary model explains crisis cycles and indicates conditions for acute conflict over the Aegean Sea. The model can be reformulated using Malthusian and linear dynamics (Friedman, 1991). Nevertheless, such a reformulation requires intricate learning assumptions, such as nonlinear growth rates or linear rates of changes in hawk-dove proportions in populations. These are assumptions more difficult to justify than the dynamics based upon aggregate payoffs. The dynamics assumption of the present model is much simpler than Malthusian and linear variants.

The model can be generalized to study numerous unresolved conflicts over delimitation of territorial waters and for rivalries containing recurrent crises. There is a growing literature on repetitive conflicts among or between the same states qualified as enduring rivalries (Goertz \& Diehl, 1993, 1995). Disputes between Colombia and Venezuela in the Gulf of Venezuela, between Indonesia and Vietnam in the South China Sea, between Turkey and Greece in the Aegean Sea, between Japan and South Korea in the Sea of Japan, and between Eritrea and Yemen in the Red Sea are some such examples (Smith \& Thomas, 1998, 7980). In addition, there are recurrent crises in conflicts such as the India-Pakistan rivalry over Kashmir, the Ecuador-Peru over Cordillera del Condor, Nicaragua-Colombia over the San Andrés Archipelago, Venezuela-Guyana over Essequibo, Ethiopia-Somalia over Ogaden, Iran-United Arab Emirates over Abu Musa, Greater Tunb-Lesser Tunb islands, Afghanistan-Pakistan over Pushtunistan, redundant and border disputes between India and China and Suriname and Guyana (Brecher \& Wilkenfeld, 1997).

The approach taken here may be called an analytic narrative, as it combines analytical tools with the narrative form, paying close attention to accounts and contexts (Bates et al., $1998,10)$. The evolutionary framework implies a narrative of crises constituting a string instead of fragmented events (Büthe, 2002, 486-487). This article does not dwell on the decision of a particular leader or a government but rather on the distribution of behavior in Greek and Turkish populations.

Nowadays, there is a new government in Greece formed by Costas Karamanlis, the leader of the New Democracy Party. A government formed by the Justice and Development Party (a party with Islamic roots) rules Turkey. The two countries are going through a phase of détente and display gestures of a genuine rapprochement. The current peace over the Aegean Sea is a point in cell I of the phase diagram 1, Figure 2. This is a static description of a system at a particular time (Selten, 1991, 7) and implies that a new crisis looms over the Aegean Sea.

\section{References}

Ahnish, F. 1993. The international law of maritime boundaries and the practice of states in the Mediterranean Sea. Oxford, UK: Clarendon Press.

Akıman, N. 2000. Turkish policy towards Greece: From the brink of war to a diplomatic breakthrough, five eventful years in Athens. Lecture presented at JFK School of Government, Kokkalis Program, Harvard University. 
Allison, G. T. 1971. Essence of decision: Explaining the Cuban missile crisis. Glenview, IL: Scott, Foresman.

Bahcheli, T. 1990. Greek-Turkish relations since 1955. Boulder, CO: Westview.

Bahcheli, T. 2000. Turkish policy toward Greece. In Turkey's new world, ed. A. Makowsky and S. Sayari, 131-152. Washington D.C.: Washington Institute for Near East Policy.

Bates, R., A. Greif, M. Levi, J. L. Rosenthal, and B. Weingast, 1998. Analytic narratives. Princeton, NJ: Princeton University Press.

Blainey, G. 1988. The causes of war. New York: Free Press.

Brecher, M., and J. Wilkenfeld. 1997. A study of crisis. Ann Arbor: The University of Michigan Press.

Büthe, T. 2002. Taking temporality seriously: Modeling history and the use of narratives as evidence. American Political Science Review 96: 481-493.

Clogg, R. 1983. Troubled alliance: Greece and Turkey. In Greece in the 1980s, ed. R. Clogg, 123-143. London: Macmillan.

Constas, D., Ed. 1991. The Greek-Turkish conflict in the 1990s. London: Macmillan.

Coufoudakis, V. 1985. Greek-Turkish relations, 1973-1983: The view from Athens. International Security 9: 185-217.

Coufoudakis, V. 1993. PASOK and Greek-Turkish relations. In Greece, 1981-89: The populist decade, ed. R. Clogg, 167-180. London: St. Martin's Press.

Couloumbis, T. 1983. The United States, Greece, and Turkey: The troubled triangle. New York: Praeger.

Dixit, A., and B. Nalebuff. 1991. Thinking strategically: The competitive edge in business, politics, and everyday life. New York: Norton.

Fearon, J. 1994. Signaling versus the balance of power and interests. Journal of Conflict Resolution 38: 236-269.

Friedman, D. 1991. Evolutionary games in economics. Econometrica 59: 637-666.

Friedman, D. 1998. On economic applications of evolutionary game theory. Journal of Evolutionary Economics 8: 15-43.

Fudenberg, D., and D. Levine. 1998. The theory of learning in games. Cambridge, MA: MIT Press.

Goertz, G., and P. Diehl. 1993. Enduring rivalries: Theoretical constructs and empirical patterns. International Studies Quarterly 37: 147-171.

Goertz, G., and P. Diehl. 1995. The initiation and termination of enduring rivalries: The impact of political shocks. American Journal of Political Science 39: 30-52.

Hensel, P. 1994. One thing leads to another: Recurrent militarized disputes in Latin America, 18161986. Journal of Peace Research 31: 281-297.

Huth, P. 1998. Standing your ground: Territorial and international conflict. Ann Arbor: The University of Michigan Press.

Huth, P., S. Bennett, and C. Gelpi. 1993. The escalation of great power militarized disputes: Testing rational deterrence theory and structural realism. American Political Science Review 87: 609623.

Huth, P., and B. Russett. 1993. General deterrence between enduring rivals: Testing three competing models. American Political Science Review 87: 61-73.

Kandori, M., G. Mailath, and R. Rob. 1993. Learning, mutation, and long run. Econometrica 61: $29-56$.

Kazamias, A. 1997. The quest for modernization in Greek foreign policy and its limitations. Mediterranean Politics 2: 71-94.

Krebs, R. 1999. Perverse institutionalism: NATO and the Greco-Turkish conflict. International Security 53: 343-377.

Larrabee, S. 1992. Instability and change in the Balkans. Survival 34: 31-49.

Leng, R. 1983. When will they ever learn? Coercive bargaining in recurrent crises. Journal of Conflict Resolution 27: 379-419.

Leng, R. 1988. Crisis learning games. American Political Science Review 82: 179-194.

Leng, R. 2000. Bargaining and learning in recurring crises: The Soviet-American, Egyptian-Israeli, and Indo-Pakistani rivalries. Ann Arbor: The University of Michigan Press.

Levy, J. 1994. Learning and foreign policy: Sweeping a conceptual minefield. International Organization 48: 279-312. 
Maoz, Z., and B. D. Mor. 1999. Learning and the evolution of enduring international rivalries: A strategic approach. Conflict Management and Peace Science 17: 1-43.

Nalebuff, B. 1986. Brinkmanship and nuclear deterrence: The neutrality of escalation. Conflict Management and Peace Science 9: 19-30.

Papacosma, V. 1996. More than rocks: The Aegean's discordant legacy. Mediterranean Quarterly 7: 75-96.

Powell, R. 1990. Nuclear deterrence theory. Cambridge, UK: Cambridge University Press.

Powell, R. 1999. In the shadow of power: States and strategies in international politics. Princeton, NJ: Princeton University Press.

Pridham, G. 1991. Linkage politics theory and the Greek-Turkish rapprochement. In The GreekTurkish conflict in the 1990s: Domestic and external influences, ed. D. Constas, 72-88. New York: St. Martin's Press.

Schelling, T. 1960. The strategy of conflict. Cambridge, MA: Harvard University Press.

Selten, R. 1991. Evolution, learning, and economic behavior. Games and Economic Behavior 3: 3-24.

Smith, R., M. Sola, and F. Spagnolo. 2000. The prisoner's dilemma and regime-switching in the Greek-Turkish arms race. Journal of Peace Research 37: 737-750.

Smith, R., and B. Thomas, 1998. Island disputes and the Law of the Sea: An examination of sovereignty and delimitation disputes. In Security flashpoints: Oil, islands, sea access and military confrontation, ed. M. H. Nordquist and J. N. Moore, 55-104. Hague: Nijhoff.

Snyder, G., and P. Diesing, 1977. Conflict among nations. Princeton, NJ: Princeton University Press.

Thompson, W. 1995. Principal rivalries. Journal of Conflict Resolution 39: 195-223.

Veremis, T. 1984. Greek security: Issues and positions. In Greece and Turkey: Adversity in alliance, ed. J. Alford, 1-42. Hants: Gower.

Wilson, A. 1984. The Aegean dispute. In Greece and Turkey: Adversity in alliance. ed. J. Alford, 90-130. Hants: Gower. 